\title{
Jaki właściwie jest dziwny świat? O znaczeniu przymiotnika dziwny i jego bliskoznaczników
}

Słowa klucze: przymiotnik; 'dziwność'; łączliwość; semantyka; definiowanie

Ke y w o r d s: adjective; 'strangeness'; connectivity; semantics; defining

1. Dziwni mogą być ludzie, inne istoty czy obiekty przejawiające cechy właściwe ludziom (np. dziwne stwory, zjawy, ufoludki), dziwne bywają rzeczy (np. dziwny dzbanek, pojazd, stót), ale też zdarzenia (np. dziwna sytuacja, lekcja, dziwny przypadek) lub stany uczuć (np. dziwne uczucie, dziwny strach, dziwna tęsknota). Poszukiwania zjawiska, któremu z całą pewnością nie można byłoby przypisać cechy dziwności, prowadzą do wniosku - być może zbyt pochopnego - że w zasadzie wszystko może być dziwne. To stanowi podstawową trudność opisu tytułowego słowa. Bierze się ona $\mathrm{z}$ jego szerokiej, wydawać by się mogło, że wręcz nieograniczonej dystrybucji, co istotne, niewynikającej z tendencji dominującej we współczesnym użyciu języka, czyli z mody na określone słowa, jak to jest na przykład z takimi natrętami językowymi jak generalnie, ogólnie (np. generalnie nie ma szans na zatrudnienie, ogólnie film mi się podobał), szeroki (w odniesieniu do wielkości abstrakcyjnych, np. szerokie możliwości, szerokie wplywy) czy ze swoistym neosemantyzmem coś dedykowane czemuś (np. filtr dedykowany wykrywa- 
niu samolotów, radar śledzący dedykowany temu zadaniu). Dziwny, będąc dość częstym i łatwo dostawianym do innych słów atrybutem, nie jest wyrażeniem modnym, jest za to wyrażeniem, które wydaje się potrzebne może bardziej niż niektóre inne predykaty. Dlaczego o tak wielu zjawiskach można powiedzieć, że są dziwne, co powoduje, że chętnie posługujemy się tym określeniem, co mamy na myśli, nazywając coś dziwnym, jakie są osoby, obiekty, zdarzenia, stany, którym przypisujemy tę cechę; wreszcie, nawiązując do znanej piosenki Niemena i tym samym pytania tytułowego, jaki właściwie jest dziwny świat?

Odpowiedzi na te pytania posłuży analiza łączliwości przymiotnika $d z i w$ $n y$ występującego w pozycji z formalnego punktu widzenia dla niego typowej, tj. przy rzeczowniku. Ze względu na, przyjętą na razie trochę na prawach aksjomatu, tezę o jego szerokiej dystrybucji i związanej z nią trudności we wskazaniu ograniczeń selekcyjnych, nałożonych na wyrażenia występujące w pozycji otwieranej dla frazy nominalnej, ciekawym zabiegiem wydaje się porównanie wielu możliwych połączeń, w jakie wchodzi dziwny, z kolokacjami, jakie mogą lub - co bardziej interesujące - jakich nie mogą tworzyć przymiotniki o podobnym znaczeniu. Będzie chodzić o takie wyrażenia jak: dziwaczny, nietypowy, osobliwy i specyficzny, choć jasne jest, że nie wyczerpują one repertuaru słów mogących zastępować predykat $d z i w n y$ w wielu różnych kontekstach (por. choćby nieokreślony, szczególny, odmienny, wyjątkowy). Zakładam, że ograniczenia łączliwości, jakie da się dla nich sformułować, oraz ich porównawcze zestawienie pomogą scharakteryzować cechy semantyczne właściwe tylko im, a tym samym przyczynią się do zgłębienia znaczenia kluczowego w tych rozważaniach predykatu dziwny, przynosząc jednocześnie wyjaśnienie zagadki jego bardzo swobodnej łączliwości, czyli dając odpowiedź na pytanie, jakie elementy znaczenia przymiotnika dziwny pozwalają na tak wiele jego zestawień z innymi słowami.

2. Hiperonimem wszystkich wziętych do zbadania przymiotników jest wyrażenie inny, a ściślej: inny niż a (gdzie $a$ oznacza pozostałe zjawiska w rodzaju tych branych pod uwagę). Jeśli nazywamy kogoś dziwnym mężczyzną, to uznajemy go za innego niż pozostali mężczyźni; podobnie dziwaczny mężczyzna to taki mężczyzna, który jest inny niż pozostali mężczyźni, analogicznie rzecz wygląda w wypadku pozostałych predykatów, o czym możemy 
się przekonać, próbując zanegować komponent 'inny niż_' w konstrukcjach $\mathrm{z}$ analizowanymi przymiotnikami. Taka operacja daje układy sprzeczne:

(1) *To dziwny mężczyzna, ale nie uważam, ̇̇eby byt inny niż pozostali mężczyźni.

(2) *To dziwaczny strój, ale nie uważam, żeby byt inny niż pozostałe stroje.

(3) *To nietypowa sprawa, ale nie uważam, żeby byta inna niż pozostate sprawy.

(4) *To osobliwy uśmiech, ale nie uważam, żeby byt inny niż pozostate uśmiechy.

(5) *To specyficzny zapach, ale nie uważam, żeby byt inny niż pozostałe zapachy.

Pełna postać wyrażenia stanowiącego wspólny element znaczenia charakteryzowanych przymiotników odsłania mechanizm orzekania rozpatrywanych cech, który opiera się na porównaniu z innymi zjawiskami określonego rodzaju, i jest to porównanie, które uwidacznia różnice między tym, czemu przypisujemy dziwność lub którąś z branych pod uwagę własności, a innymi bytami tej cechy pozbawionymi. Ta różnica stanowi przyczynę orzekania dziwności i pozostałych rozpatrywanych tu właściwości. Coś, co jest dziwne, dziwaczne, nietypowe, osobliwe lub specyficzne, różni się od innych rzeczy danego typu. Potwierdza to sprzeczność następujących wypowiedzeń:

(6) *Ten dzbanek nie różni się niczym od innych dzbanków, które do tej pory widziałam, ale jest to dziwny dzbanek.

(7) *Ten berecik nie różni się niczym od innych berecików, które do tej pory widziałam, ale jest to dziwaczny berecik.

(8) *Ten guzik nie różni się niczym od innych guzików, które do tej pory widziałam, ale jest to nietypowy guzik.

(9) *Ten smak nie różni się niczym od innych smaków, które do tej pory znatam, ale jest to specyficzny smak.

(10) *Ta budowla nie różni się niczym od innych budowli, które do tej pory widziałam, ale jest to osobliwa budowla.

Podobny efekt dają zestawienia w rodzaju: *dom dziwny i niczym nieróżniący się od innych domów, *chód dziwaczny i niczym nieróżniący się od in- 
nych sposobów chodzenia, *ubiera się w nietypowy sposób $i$ w sposób niczym nieróżniacy się od tego, jak ubieraja się inni, *chwila osobliwa i niczym nieróżniąca się od innych chwil, *odgłosy specyficzne i niczym nieróżniące się od innych odgłosów czy też: *dom dziwny i taki sam jak inne domy, *chód dziwaczny i taki sam jak inne sposoby chodzenia, *strój nietypowy i taki sam jak inne stroje, *chwila osobliwa i taka sama jak inne chwile, *odgłosy specyficzne i takie same jak inne odgłosy.

Inność cechująca dziwność, dziwaczność, nietypowość, osobliwość i specyficzność zwraca czyjąś uwagę, wyróżnia to, co tę cechę ma, spośród innych obiektów czy zjawisk i wiąże się z przekroczeniem normy, zrelatywizowanej jednak do indywidualnych ocen i gustów mówiącego. Badane predykaty pozostają $\mathrm{w}$ swoistym konflikcie semantycznym z przymiotnikami takimi jak np. zwykty, zwyczajny, normalny (por. Maryn 2009), ponieważ stanowią w pewnym stopniu ich przeciwieństwa, na pewno niesymetryczne, bo nie wchodzą z nimi w relację antonimii ani sprzeczności, ale ich sensy z całą pewnością się wykluczają, o czym świadczą dewiacyjne układy:

(11) *To taki normalny dziwny człowiek.

(12) *To byt zwyczajny dziwny dzień.

(13) *To taka zwykta dziwna sukienka.

(14) *To była typowa dziwna lekcja polskiego.

Por. również analogiczne zestawienia $\mathrm{z}$ pozostałymi porównywanymi przymiotnikami: *normalny dziwaczny człowiek, *zwyczajny osobliwy dzień, *zwykta nietypowa sukienka, *typowa specyficzna lekcja polskiego.

$\mathrm{W}$ poszukiwaniu pomocnych w tego rodzaju dociekaniach dewiacji językowych warto zauważyć, że choć analizowane predykaty mogą być swobodnie uzupełniane przez intensyfikatory, np. bardzo dziwna sytuacja, bardzo dziwaczny widok, bardzo osobliwy kształt kieliszka, niesamowicie nietypowa sprawa, niezwykle specyficzny gust, to raczej nie wchodzą w połączenia z maksymalizatorami, por. niedobre językowo:

(15) *On jest calkowicie dziwny.

(16) *To całkowicie dziwne matżeństwo.

(17) *To kompletnie dziwny facet. 
Por. także analogiczne połączenia z pozostałymi analizowanymi przymiotnikami: *zupetnie dziwaczna dziewczyna, *kompletnie nietypowy profesor, *calkowicie osobliwy gust, *kompletnie specyficzny rodzaj zalotów.

Na próby dostawienia wyrażeń określających maksymalne natężenie cechy podobnie reagują także inne predykaty, choćby takie jak np. ładny, skapy, muzykalny, wybuchowy, utalentowany (por. *kompletnie tadna dziewczyna, *zupetnie skapy człowiek, *atkowicie muzykalny chłopiec, *kompletnie wybuchowy nauczyciel, *zupetnie utalentowany aktor), nazywające cechy, na które na ogół nie ma się wpływu i które nie są rezultatem ukierunkowanych intencjonalnie czynności (zresztą często nieudanych), por. dobre językowo kompletnie urządzone mieszkanie / nieprzygotowany do zajęć, całkowicie niewyspany. Takie warunki spełniają w wielu kontekstach również opisywane wyrażenia, trudno jednak w tej obserwacji upatrywać znaczącego kroku naprzód, ponieważ zauważona właściwość nie jest znamienna tylko dla nich, nie wyróżnia ich spośród innych predykatów. Znalezieniu tego rodzaju cech, tj. cech właściwych tylko grupce opisywanych przymiotników, a także elementów różnicujących ich znaczenia, podporządkowana będzie dalsza część rozważań, w której analizie poddana zostanie łączliwość wszystkich pięciu wyrażeń.

3. Badanie łączliwości opisywanych przymiotników zacznę od ich charakterystyki pozytywnej, tj. wskazania połączeń, jakie dane słowo najczęściej realizuje, w dalszej kolejności przejdę do prób znalezienia cenniejszego z punktu widzenia zaplanowanych ustaleń materiału negatywnego, czyli połączeń, w które dane wyrażenia nie wchodzą. W trosce o czytelne podanie zgromadzonej reprezentacji kontekstów pierwszą część analizy przedstawię w postaci tabeli. Kolejność podania kolokacji odwzorowuje z grubsza częstotliwość wystąpień tekstowych opisywanych predykatów.

\begin{tabular}{|l|l|l|l|l|}
\hline dziwny & dziwaczny & nietypowy & osobliwy & specyficzny \\
\hline $\begin{array}{l}\text { zbieg } \\
\text { okoliczności }\end{array}$ & ksztalt & sposób & sposób & zapach / aromat \\
sen & strój & wypadek & chwila & woń \\
uśmiech & sen & przypadek & wyglad & smak \\
& widok & problem & gust & koloryt \\
& kapelusz & sprawa & wyraz twarzy & sposób \\
\hline
\end{tabular}




\begin{tabular}{|c|c|c|c|c|}
\hline dziwny & dziwaczny & nietypowy & osobliwy & specyficzny \\
\hline $\begin{array}{l}\text { sposób (mówie- } \\
\text { nia, szukania mi- } \\
\text { łości) } \\
\text { człowiek } \\
\text { niepokój } \\
\text { stwór } \\
\text { odgłos / dźwięk } \\
\text { facet } \\
\text { typ } \\
\text { klient } \\
\text { wygląd } \\
\text { widok } \\
\text { świat } \\
\text { ból } \\
\text { szum } \\
\text { nastrój } \\
\text { dzień } \\
\text { przypadek } \\
\text { kraj } \\
\text { zapach } \\
\text { wyraz twarzy } \\
\text { zamiar } \\
\text { spokój } \\
\text { zwyczaj } \\
\text { ing }\end{array}$ & $\begin{array}{l}\text { twór } \\
\text { [coś robić] } \\
\text { w dziwaczny } \\
\text { sposób } \\
\text { długi cień } \\
\text { ruch dtonia } \\
\text { pochód } \\
\text { myśl } \\
\text { budowla } \\
\text { pojazd/wehikut } \\
\text { pomyst } \\
\text { tryb życia } \\
\text { osobnik } \\
\text { dzieciak } \\
\text { zamiar } \\
\text { akcent } \\
\text { kraj } \\
\text { plątanina liter } \\
\text { zwyczaj zamyka- } \\
\text { nia jedzenia na } \\
\text { klucz }\end{array}$ & $\begin{array}{l}\text { sytuacja } \\
\text { dźwięk } \\
\text { zapach } \\
\text { kolor } \\
\text { strój } \\
\text { program } \\
\text { wychowawczy } \\
\text { pomyst } \\
\text { prezent } \\
\text { przebieg } \\
\text { [czegoś] } \\
\text { kolekcjoner } \\
\text { egzystencjalista } \\
\text { profesor } \\
\text { gimnazjalny } \\
\text { wentylator } \\
\text { zestaw } \\
\text { koń } \\
\text { dzień } \\
\text { okaz } \\
\text { parowóz } \\
\text { pożar }\end{array}$ & $\begin{array}{l}\text { kształt } \\
\text { uśmiech } \\
\text { zmyst } \\
\text { wrażliwości } \\
\text { spryt } \\
\text { dźwięk } \\
\text { rytm } \\
\text { akcent } \\
\text { zwyczaj gadania } \\
\text { do siebie } \\
\text { gatunek } \\
\text { skapstwa } \\
\text { logika chorego } \\
\text { na schizofrenię } \\
\text { pieszczota } \\
\text { pokusa } \\
\text { człowiek } \\
\text { postać } \\
\text { w kapeluszu } \\
\text { fryzura } \\
\text { cisza } \\
\text { składnia } \\
\text { uwaga }\end{array}$ & $\begin{array}{l}\text { język } \\
\text { charakter } \\
\text { gust } \\
\text { eksperyment } \\
\text { region } \\
\text { teren } \\
\text { sposób } \\
\text { chodzenia } \\
\text { hałas } \\
\text { urok wsi } \\
\text { uśmiech } \\
\text { problem } \\
\text { postawa } \\
\text { konstrukcja } \\
\text { rodzaj zalotów } \\
\text { stosunek } \\
\text { do kobiet }\end{array}$ \\
\hline
\end{tabular}

W analizie próbki zestawień wyrazowych z udziałem badanych przymiotników trzeba przede wszystkim uwzględnić rodzaj implikowanego przez nie argumentu, który może być przedmiotowy, czyli nazywający rzeczy, a także osoby, lub nieprzedmiotowy, czyli taki, który nazywa zdarzenia, stany rzeczy, byty abstrakcyjne różnego rodzaju. Biorąc pod uwagę powyższe dane, kategorycznych ograniczeń łączliwości nie da się sformułować w zasadzie dla żadnego z opisywanych wyrażeń. Zgodnie z założeniami wstępnymi 
najbardziej liberalny pod względem ograniczeń selekcyjnych jest centralny w tych badaniach predykat dziwny. W wypadku pozostałych pojawiają się pewne wątpliwości dotyczące niektórych połączeń. I tak, dziwaczny, mimo że daje się dostawić i do nazw osób, rzeczy, i do nazw nierzeczy, najbardziej pasuje do rzeczowników określających wrażenia wizualne, to, co percypujemy za pomocą wzroku lub co może zostać w jakiś sposób (choćby w postaci wyobrażenia) zwizualizowane, raczej nie współgra on z wyrażeniami, których odniesienie kojarzy się z innymi zmysłami, por. dyskusyjne ?dziwaczny zapach, ?dziwaczny smak, lub też z nazwami uczuć, np. ?dziwaczna tęsknota, ?dziwaczny spokój (choć w NKJP są 4 takie konteksty) ${ }^{1}$. Poza tym trudno wyobrazić sobie desygnaty takich dyskusyjnych zestawień jak ?dziwaczne oczy, ?dziwaczne ręce czy ?dziwaczny nos, choć już dziwaczne włosy nie budzą wątpliwości, ponieważ ich wygląd nierzadko bywa rezultatem czyjegoś celowego działania. Pod takimi warunkami dałoby się zaakceptować także poprzedzające je połączenia: jeślibyśmy orzekali dziwaczność o oczach, rękach czy nosie nie człowieka, lecz skonstruowanej przez kogoś postaci, np. lalki (ewentualnie w wypadku człowieka oceniali efekt pracy chirurga plastycznego), to miałoby to sens, jednak w odniesieniu do naturalnych cech ludzi czy innych istot żywych byłoby to niemożliwe. Własność tę przypisuje się bowiem czemuś, co możemy w jakiś sposób kształtować.

Przymiotnik nietypowy swobodnie wchodzi w połączenia w rodzaju tych przytoczonych wyżej, zastanawiające są natomiast jego zestawienia z wyrażeniami pełniącymi funkcję hiperonimów z bardzo ograniczonymi możliwościami użycia ich w funkcji hiponimów (chodziłoby więc o nadnazwy generalne, powiedzmy), np. ?nietypowy czlowiek, ?nietypowa osoba, ?nietypowa istota (por. z bezdyskusyjnie dobrymi połączeniami nietypowy profesor, nietypowy fryzjer, nietypowa babcia). Dałoby się je zaakceptować, gdyby rozważana cecha była orzekana w porównaniu do innych istot, np. nieziemskich czy nadludzkich. Pod względem semantycznym nietypowy jest przeciwień-

1 Przytoczone połączenia opatruję znakiem zapytania, a nie surowszą, bo potępiającą gwiazdką, ponieważ obudowane stosownym kontekstem, zwłaszcza jako elementy obrazowo snutej narracji, stają się akceptowalne, np. Ogarnęła go nagle jakaś dziwaczna tęsknota za minionymi snami. Nie zmienia to faktu, że należą one do zestawień rzadkich, nawet sporadycznych, funkcjonujących w moim odczuciu jako swoiste indywidualizmy. Uwaga ta dotyczy również analogicznie oznaczonych przykładów z udziałem przymiotników specyficzny i osobliwy rozważanych kilka akapitów dalej. 
stwem typowego, a więc stanowi zaprzeczenie cech najczęściej przypisywanych obiektom należącym do danej kategorii.

Predykat specyficzny najwięcej połączeń tworzy z wyrażeniami określającymi zmysły, głównie zapach i smak, a także z określeniami dotyczącymi cech czyjegoś wyglądu. Zastanawiające natomiast wydają się jego połączenia z nazwami rzeczy. Ani zestawienia ?specyficzna rzecz, ?specyficzny przedmiot, ani kolokacje z hiponimami rzeczowników z przytoczonych połączeń, np. ?specyficzny samochód, ?specyficzny kubek, nie znajdują potwierdzenia $\mathrm{w}$ danych korpusowych. Jeśli specyficzny przedmiot, to jedynie przedmiot zainteresowań na przykład (zatem odniesienie do nierzeczy), na podobnych warunkach dopuszczalne jest zestawienie specyficzny dom - nie w odniesieniu do budynku, lecz do sposobu funkcjonowania zamieszkujących go osób.

Podobnie rzecz się ma z przymiotnikiem osobliwy. ?Osobliwy przedmiot lub ?osobliwa rzecz, z wyłączeniem możliwości odniesienia ich do bytów niematerialnych (np. osobliwy przedmiot działalności, osobliwa rzecz jako komentarz zdarzenia), stanowią połączenia dyskusyjne. Ich nieadekwatność można by wyjaśniać tym, że słowo to zarówno strukturalnie, jak i etymologicznie związane jest z osoba (por. Boryś 2005: 400, Buttler 1978: 243-244²). Choć w danych korpusowych można znaleźć kilka przykładów przeczących temu spostrzeżeniu, np. osobliwy park, osobliwa roślina czy najbardziej kontrowersyjne osobliwa krowa. Pierwsze z nich dałoby się interpretować podobnie jak dom w przywołanym wyżej połączeniu specyficzny dom, chodziłoby więc nie tyle o samo miejsce, ile na przykład o miejsce, w którym dzieją się jakieś niecodzienne zdarzenia ${ }^{3}$. Pozostałe są zastanawiające na tyle, że wywołują refleksję na temat specyfiki danych korpusowych.

2 D. Buttler w opisie zmian semantycznych przymiotnika osobliwy zwraca uwagę na to, że najpierw był on związany z osobą i miał znaczenie szerokie na tyle, że można było go stosować zamiennie ze słowami osobny czy osobisty, później zaś zaczęto używać go w znaczeniu 'związany tylko z daną osobą' (podkreślenie D.B.), podobnie jak wyrażenia szczególny czy niezwykły.

3 Warto zaznaczyć, że przymiotnik osobliwy może być używany w celu wyrażenia w sposób złagodzony i nieeksplicytny negatywnej oceny komentowanego obiektu lub zjawiska (por. uwagę ze SWJP: 698: 'często z odcieniem dezaprobaty'). Wydaje się, że właściwość ta dotyczy także pozostałych opisywanych jednostek, zwłaszcza predykatów specyficzny i dziwny. Jednak orzekanie za ich pomocą określonych cech bynajmniej nie implikuje na warunkach koniecznych negatywnej oceny komentowanych zjawisk, por. akceptowalne zdania: Te perfumy maja specyficzny zapach, ale podobaja mi się, To dziw- 
Nie da się podważyć ich przydatności w opisie języka. Możliwość wyszukania kontekstów autentycznych chroni badacza języka przed obracaniem się wciąż wokół tych samych przykładów, zwłaszcza że bywają one nieempiryczne, poza tym pomaga zweryfikować niektóre spostrzeżenia: umocnić je lub przeciwnie - odrzucić. Niemniej jednak nie można traktować tych cennych danych bezkrytycznie, nie mogą i nie powinny one działać na zasadzie wyroczni, tj. mieć mocy rozstrzygającej. Powodów jest kilka. Po pierwsze, mylący może okazać się kontekst. Pomimo że wyszukiwarki korpusowe zapewniają dość rozbudowany kontekst zdaniowy, a nawet tekstowy, może okazać się on niewystarczający w wypadku zastosowania przez autora tekstu np. wyjątkowej konwencji stylistycznej, powiedzmy, stylizacji lub żartu. Po drugie, reprezentatywny i zrównoważony korpus musi zawierać teksty pochodzące z literatury pięknej czy z publicystyki (por. Przepiórkowski, Bańko, Górski, Lewandowska-Tomaszczyk (red.) 2012: 33-34), zwłaszcza te pierwsze, przyjmowane bez należytej refleksji, można w badaniach wykorzystać niewłaściwie. Trzeba bowiem mieć na uwadze to, że niektóre z wyszukanych fragmentów tekstów mogą być efektem pewnych - jak rzecz trafnie ujmuje Bogusławski (Bogusławski 2008) - działań na narzędziach językowych, czyli subtelnych zabaw językiem, do których skorzy są zwłaszcza ci, których sprawność językowa jest ponadprzeciętna, czyli właśnie twórcy tekstów literackich. Dotyczy to z pewnością niezbyt dużej liczby przykładów, do których jednak należałoby zaliczyć przywołaną wyżej osobliwą krowę stworzoną i opisaną przez Hannę Kostyro w „Klechdach domowych”. Niewątpliwie współgra ona z innymi elementami opowieści rozgrywającej się w krainie dziwów, ale poza kontekstem utworu stanowi połączenie językowe w moim odczuciu więcej niż osobliwe ${ }^{4}$, bo akceptowalne w zasadzie tylko wówczas, gdy się rzeczoną krowę w pewnym stopniu upersonifikuje, jak np. w zdaniu Byta to krowa wielce osobliwa, szczerze nie znosiła swojej gospodyni i w czasie dojenia wściekle ryczała. Dlatego między innymi ostatecznym czynnikiem rozstrzygającym problem adekwatności określonego kontekstu może

ny mężczyzna, ale dzięki temu jest interesujacy, dlatego podoba mi się nawet bardziej niż inni mężczyźni, których znam.

4 Podobnie rzecz się ma z osobliwą roślina odnoszącą się do biblijnego krzaka gorejącego, który płonął, ale się nie spalał. Zjawisko to interpretuje w „Opowieściach biblijnych" Zenon Kosidowski. 
być wyłącznie, podnoszona przez N. Chomsky’ego (por. Stanosz 1977: 15), intuicja językowa badacza.

4. Przeprowadzoną wyżej obserwację łączenia i wykluczania się sensów należy traktować jako wprowadzenie do pogłębionej analizy znaczenia badanych predykatów. Ze względu na brak opracowań semantycznych na opisywany temat zacznę od jedynych prób zdefiniowania badanych wyrażeń, jakimi są charakterystyki zamieszczone w wybranych słownikach współczesnej polszczyzny. Główną tendencją $\mathrm{w}$ definiowaniu rozpatrywanych przymiotników jest tworzenie opisów powiązanych ze sobą na zasadzie wzajemnych odwołań prowadzących do cyrkularności bezpośredniej lub też pośredniej. Dotyczy to przede wszystkim definicji słów dziwny, dziwaczny i osobliwy, charakterystyki wyrażeń nietypowy i specyficzny są w zasadzie wolne od ciągów wyliczeniowych, w sposób szczególny sprzyjających błędnym kołom. W objaśnieniu znaczenia przymiotnika dziwny uczestniczy przede wszystkim słowo osobliwy, które w SJPSz stanowi niejako centrum charakterystyki semantycznej (por. SJPSz, t. 1: 510 oraz USJP, t. 1: 777: dziwny - 'odznaczający się czymś o sobliwym, zwracający na siebie uwagę tą osobliwością; niezwykły, szczególny, nieokreślony, niezrozumiały'5), zaś w pozostałych definicjach słownikowych pojawia się w ciągu wyliczeniowym obok takich wyrażeń, jak: szczególny, nietypowy, niezrozumiały, zagadkowy, dziwaczny (por. SWJP: 224, PSWP, t. 10: 201-202). Bardzo podobne semantyczne przybliżenia, tyle że uzupełnione o kilka innych wyrażeń, np. wyjątkowy, nadzwyczajny, zadziwiajacy (por. SJPSz, t. 2: 554, USJP, t. 2: 1317), odmienny (SWJP: 698), stosuje się w opisie przymiotnika osobliwy. Natomiast $d z i-$ wacznemu - w myśl rozwiązań definicyjnych przedstawionych w niektórych słownikach - pod względem znaczenia najbliżej jest do osobliwego (por. SWJP: 224: 'odbiegający pod jakimś względem od normy, wyróżniający się czymś niezwykłym, o s o bl iw y m; nietypowy, cudaczny, śmieszny, osobliwy', por. też PSWP, t. 10: 199, USJP, t. 1: 777), choć w jego charakterystyce uczestniczą również słowa, których nie ma w opisach pozostałych rozpatrywanych wyrażeń, takie jak śmieszny i cudaczny (por. także SJPSz, t. 1: 510, USJP, t. 1: 777). Inaczej definiuje się te trzy wyrażenia w ISJP. Znaczenie przymiotnika dziwaczny objaśnia się za pomocą słów dziwny i niezwykty,

\footnotetext{
5 Wszystkie wyróżnienia fragmentów definicji zostały wprowadzone przeze mnie.
} 
ale nie w układzie wyliczeniowym, lecz za pomocą alternatywy z udziałem tych przymiotników (por. ISJP, t. 1: 361: 'dziwaczne osoby, rzeczy lub zjawiska są dziwne lub niezwykłe często w sposób, który wydaje się nam nieuzasadniony'). Taki układ zastosowany został także w charakterystyce dziwnego, tyle że w funkcji definiensa występuje tu para niezwykte lub niezrozumiałe (por. ISJP, t. 1: 361: 'coś, co jest dziwne, jest n i e z w y kłe lub niezrozumiałe i zwraca na siebie uwagę). W opisie znaczenia przymiotnika osobliwy wykorzystane zostało pojęcie niezwykłości (por. ISJP: 1192: 'osobliwe rzeczy, osoby, zjawiska itp. różnią się znacznie od innych rzeczy, osób lub zjawisk tego samego rodzaju i zwracają uwagę swoją niezw y kło śc i ą'). Natomiast w charakterystykach wyrażeń nietypowy i specyficzny dominują zasadniczo bardzo podobne ustalenia, mimo że naturalnie zostały one różnie wysłowione. Nietypowy potraktowany został jako semantyczne przeciwieństwo typowego (por. SJPSz, t. 2: 366: 'n i e mają cy cech typow y ch; odmienny od przyjętego szablonu; rzadko występujący', SWJP: 611: 'pozbawiony cech typow ych; inny niż zwykle, niż reszta; rzadko występujący', USJP, t. 2: 976: 'n i e mają c y c e ch ty p ow ych dla określonej serii przedmiotów, zjawisk itp.'), wyjątkiem jest ISJP, w którym definiuje się to słowo wprawdzie prościej niż w pozostałych słownikach (por. ISJP, t. 1: 1019: 'nietypowe osoby, rzeczy, zjawiska itp. zdecydowanie różnią się od większości osób, rzeczy lub zjawisk tego samego rodzaju'), ale jednocześnie pozbawia się tej formuły eksplicytnego wyrażenia cechy odróżniającej to wyrażenie od predykatów pokrewnych semantycznie. W opisie specyficznego wyeksponowano zaś zgodnie to, że właściwość ta jest charakterystyczna tylko lub nawet wyłącznie dla kogoś / czegoś (por. ISJP, t. 2: 642: 'specyficzne cechy jakichś osób, rzeczy, miejsc itp. s ą ty $1 \mathrm{k}$ o

${ }^{6}$ USJP jest jedynym opracowaniem leksykograficznym, w którym przymiotnik nietypowy potraktowany został jako wyrażenie polisemiczne. Drugie znaczenie tego predykatu zostało objaśnione za pomocą sformułowania 'rzadko występujący, spotykany' i zilustrowane przykładami: Ma w mieszkaniu same nietypowe rośliny. Nietypowe objawy choroby (USJP, t. 2: 976). Rozstrzygnięcie, które z dwóch znaczeń reprezentują tekstowe użycia tego wyrażenia, jest trudne o tyle, że cechy zinterpretowane jako drugie znaczenie implikują treści, za pomocą których objaśnia się znaczenie pierwsze. Wprawdzie zauważona zależność nie jest obustronna (coś, co jest nietypowe, nie musi być rzadko spotykane, por. Nietypowe objawy anginy są w ostatnim czasie stosunkowo często spotykane), ale ze względu na brak elementów zawężających w sposób konieczny drugie z wyodrębnionych znaczeń, propozycję ich rozgraniczania skłonna jestem uznać za chybioną. 
dla nich charakterystyczne', SJPSz, t. 3: 285 oraz USJP, t. 3: 1315: 'właściwy wyłącznie komuś lub czemuś, charakterystyczny dla kogoś lub czegoś; swoisty', SWJP: 1041: 'charakterystyczny dla kogoś, czegoś; typowy dla kogoś, czegoś, właściwy komuś, czemuś; swoisty', PSWP, t. 39: 404: 'charakterystyczny dla kogoś bądź czegoś, właściwy danej osobie lub rzeczy').

Spośród przywołanych wyżej propozycji definicyjnych skłonna jestem przyjąć dwie: jedną bez specjalnych zastrzeżeń, drugą pod pewnymi warunkami. Pierwsza dotyczy opisu znaczenia wyrażenia nietypowy, druga wyrażenia specyficzny. O trafności postulatów semantycznych przyjętych w opisach słownikowych przymiotnika nietypowy świadczyć może sprzeczność zdań:

(18) *To byto zachowanie nietypowe dla Piotra, ale to zachowanie byto takie jak inne zachowania Piotra.

(19) *Ewa nosiła stroje nietypowe dla urzędniczki, ale stroje Ewy byty takie jak stroje innych urzędniczek.

Takiego efektu nie daje jednak próba przetestowania zgłaszanego przez większość leksykografów ujęcia istoty specyficzności w kategoriach właściwości charakterystycznej ty 1 k o (lub nawet wyłącznie) dla obiektu lub zjawiska, o którym się tę cechę orzeka. Por. akceptowalne zdania:

(20) Jego skóra wydziela specyficzny zapach, ale nie jest tak, że ten zapach jest charakterystyczny tylko dla jego skóry.

(21) Piotr preferuje specyficzny rodzaj zalotów, ale nie jest tak, że ten rodzaj zalotów jest charakterystyczny tylko dla Piotra.

Osoba, o której jest powiedziane w przykładzie (20), nie musi być jedyną, której zapach można określić jako specyficzny, podobnie rzecz wygląda z rodzajem zalotów Piotra z przykładu (21), z pewnością jest więcej osób, o których zalotach można orzec tę cechę. Chociaż trzeba też zauważyć, że na specyficzność odnoszącą się do różnych obiektów czy zjawisk prawdopodobnie każdorazowo będą się składały inne elementy. Trudno rozstrzygnąć, czy możliwe są dwa obiekty specyficzne na identycznych warunkach (np. dwa identyczne specyficzne zapachy), pewnie tak, ale dla orzekające- 
go tę własność taka precyzja wcale nie jest istotna, chodzi mu raczej o podkreślenie, że zauważona inność komentowanej cechy kojarzy mu się właśnie z tym (oto) określonym, jednostkowym obiektem / zjawiskiem (np. zapachem czy sposobem zalecania się do kogoś). Niewątpliwie więc poszukiwana różnica między specyficznym a pozostałymi branymi pod uwagę przymiotnikami faktycznie będzie oscylować wokół podkreślenia indywidualności danej cechy, czegoś w rodzaju wyłączności, traktowanej swoiście, bo zawężonej do referencyjnego tu i teraz. Przekonuje do tego sprzeczność poniższych zdań:

(22) *Jego skóra wydziela specyficzny zapach, ale nie jest tak, że czując ten zapach, można wiedzieć, że to zapach wtaśnie jego skóry.

(23) *Piotr preferuje specyficzny rodzaj zalotów, ale nie jest tak, że widzac jego zaloty, można wiedzieć, że to wtaśnie zaloty Piotra.

(24) *Zosia ma specyficzny chód, ale nie jest tak, że widzac ten chód, można wiedzieć, że to właśnie Zosi chód.

(25) *To jest specyficzny śmiech, ale nie jest tak, że stysząc ten śmiech, można wiedzieć, że to wtaśnie ten (oto) śmiech.

Specyficzność powoduje, że obiekt lub zjawisko, któremu ta właściwość przysługuje, zawiera jakiś rys indywidualny, rozpoznawalny na podstawie doświadczania tej cechy, odbieranej zwykle zmysłami (stąd właśnie częste połączenia w rodzaju specyficzny zapach / smak). Z pewnością jednak należałoby poszukać trochę innego eksplikacyjnego wysłowienia tej interpretacji niż zapis zorganizowany wokół elementu 'tylko'.

Przymiotnik osobliwy, dość chętnie wykorzystywany jako definiens (lub też składnik definiensa) innych porównywanych wyrażeń, na pewno nie jest prostszy semantycznie od żadnego z badanych predykatów. Najtrafniej jego znaczenie przybliża charakterystyka z ISJP, choć na potrzeby specjalistycznego opisu trzeba by ująć prościej wykorzystane w niej pojęcie niezwykłości czy też zestaw tych cech, które autor definicji zdecydował się nazwać w taki sposób. Inność czegoś osobliwego sprowadza się według mnie do tego, że w sposób wyraźny wyróżnia się to spośród różnych innych obiektów czy zjawisk danego rodzaju spotykanych powszechnie. Byłaby to więc właściwość sytuująca się nie tyle w opozycji do cech przejawiających się w sposób typowy, najczęściej spotykany, wpisujący się w pewien skonwencjonalizowany wzorzec (jak w wypadku specyficzności), ile do ró ż n o r o d n o śc i, na 
tle której rzeczona własność najbardziej zwraca czyjąś uwagę. Por. sprzeczne zdania:

(26) *Miała osobliwy uśmiech, ale jej uśmiech nie byt inny niz uśmiechy różnych innych osób.

(27) *Złościła się w osobliwy sposób, ale nie złościła się w sposób inny od tego, w jaki złościły się różne inne osoby.

(28) *Ten kieliszek ma osobliwy ksztalt, ale kształt tego kieliszka nie jest inny niż kształt różnych innych kieliszków.

Najbliższy, choćby strukturalnie, centralnemu w tej analizie dziwnemu jest przymiotnik dziwaczny, którego znaczenie w przytoczonych definicjach (wszystkich poza opisem z ISJP) jest objaśniane wyjątkowo heterogenicznie. Jedynym pozytywnym elementem opisów słownikowych wydaje się przybliżenie jego treści za pomocą takich słów jak śmieszny i cudaczny. Bo rzeczywiście dziwaczność jest cechą kojarzoną z tymi przymiotami, głównie ze względu na to, że - jak pokazała charakterystyka łączliwości wyrażenia dziwaczny - przypisuje się ją wówczas, gdy istnieje możliwość wizualizacji tego, do czego się odnosi. Coś, co jest dziwaczne, jest inne niż reszta w sposób dobrze widoczny, co ważne-dotyczy to również bytów niekonkretnych, takich jak np. sny czy myśli, które również na rozmaitych zasadach mogą przyjmować w naszych umysłach postać pewnych obrazów czy wizji. Potwierdzenie tej intuicji można znaleźć w przykładach:

(29) *Miała dziwaczny chód, ale trudno było zobaczyć / nie było widać, że jej chód jest inny niż chód pozostatych osób.

(30) *To jest dziwaczny kapelusz, ale trudno zobaczyć / nie widać, że ten kapelusz jest inny niż pozostałe kapelusze.

W kontekście powyższych ustaleń przymiotniki zestawione porównawczo z dziwnym można by próbować orientacyjnie definiować za pomocą następujących formuł:

(31) nietypowy (dla kogoś / czegoś) 'nie taki jak większość a' 
(32) specyficzny

'inny niż a

w sposób, który powoduje, że można wiedzieć, że to jest to, o czym mowa'

(33) osobliwy

'inny niż a

i taki, że wśród różnych a najbardziej zwraca czyjąś uwagę’

(34) dziwaczny

'w sposób dobrze widoczny inny niż a

i taki, że ktoś może czuć coś z tego powodu’

gdzie $a$ oznacza pozostałe zjawiska w rodzaju tych branych pod uwagę. Wspólną częścią znaczenia wszystkich definiowanych przymiotników jest element 'inny niż a'. Nie został on jednak wyrażony explicite w definicji wyrażenia nietypowy (por. (31)), co podyktowane jest uniknięciem efektu tautologii, który spowodowałoby dostawienie tego elementu do komponentu objaśniającego znaczenie tej jednostki. Proponowany definiens w tym wypadku należałoby traktować jako hiponim wyrażenia 'inny niż a', który ujmując jego treść w sposób bardziej szczegółowy, odkrywa istotną, bo dystynktywną różnicę. W definicjach pozostałych trzech przymiotników została ona skomponowana w układzie z elementem 'inny niż a'. I choć w każdej z czterech zaproponowanych wyżej charakterystyk decydująca o odrębności jednostki różnica wyrażona jest podobnie, to jednak koncentruje się ona za każdym razem na innej cesze. Nietypowość stawia w opozycji do większości przejawów danej właściwości, specyficzność odróżnia poprzez swego rodzaju indywidualność realizacji danej cechy, idącą w kierunku wyłączności przypisanej do określonego obiektu, osoby czy zjawiska, zaś osobliwość - poprzez inność zwracającą czyjąś uwagę na tyle, że wyróżnia dane zjawisko spośród innych różnorodnych ${ }^{7} ;$ w końcu dziwaczność ujmuje jako inność przejawiającą się w sposób dobrze widoczny, dający się (choćby wyobrażeniowo w wypadku cech niefizycznych, np. takich jak myśli czy sny) wizualizować, i mogącą $\mathrm{w}$ związku z tym wywoływać różne uczucia, wydaje

7 Testowane w przykładach (26)-(28) sformułowanie ‘inny niż różne inne a’ zostało w formule (33) ujęte z perspektywy efektu, jaki wywołuje ta cecha, i zapisane w postaci bardziej rozczłonkowanej. 
się, że także oceny (stąd postrzeganie zjawisk dziwacznych na przykład jako śmieszne).

Jak zaznaczyłam, są to eksplikacje jedynie rozpoznawcze, w jakiejś mierze intuicyjne, bo dokonane na podstawie obserwacji jeszcze niewystarczająco pogłębionej. Dostawienie do grupy opisywanych predykatów innych przymiotników, na przykład tych, które konstytuują słownikowe ciągi wyliczeniowe, niewątpliwie skomplikowałoby sprawę, można bowiem przypuszczać, że za pomocą formuły (33) dałoby się objaśniać znaczenie również takich wyrażeń jak szczególny, niezwykły czy wyjątkowy. Rozwiązanie m.in. tego problemu jest niewątpliwie potrzebne, jednak podjęcie się go w obrębie tego tekstu spowodowałoby przesunięcie punktu ciężkości na zagadnienia zbyt odległe od centralnego przedmiotu badań.

5. Z punktu widzenia przyjętej w tych rozważaniach hierarchii, dotyczącej wziętych do zbadania predykatów, dziwności należy się najwięcej uwagi. Po pierwsze, nie jest przypadkiem to, że w ISJP wykorzystuje się to słowo jako definiens przymiotnika dziwaczny. Jest ono na pewno prostsze semantycznie od pozostałych wyrażeń, choć nie nadaje się na definiens każdego z nich, bo mimo że dziwaczny chód to zarazem dziwny chód (por. *To $d z i$ waczny chód, ale to nie jest dziwny chód), to specyficzny smak nie musi być dziwnym smakiem, nietypowe zachowanie nie musi być zachowaniem dziwnym, a osobliwa chwila niekoniecznie zasługuje na nazwanie jej dziwną. Oczywiście te atrybuty, jako że są sobie bliskie, mogą towarzyszyć jedne drugim, ale nie zawsze tak jest. Po drugie, trzeba mieć w pamięci swobodną, a ściślej: niepodlegającą żadnym obostrzeniom, łączliwość tego przymiotnika i związaną z nią lekkość jego używania. Chciałoby się ponownie zapytać, powtarzając tym samym po części refleksje otwierające te rozważania, co powoduje, że tak często sięgamy po to wyrażenie.

Zwykle wydaje nam się ono adekwatne wtedy, gdy nie do końca potrafimy określić istotę tego, co zwraca naszą uwagę czy też jest inne niż reszta. Nie potrafimy powiedzieć, jakie dokładnie jest to, co uznajemy za dziwne. W grę wchodzi więc na pewno sprawa rozumienia i związanej z nią wiedzy, a właściwie niewiedzy. Tytułowy dziwny świat to świat, którego nie rozumiemy, czegoś o nim nie wiemy lub raczej to, co o nim wiemy, nie przystaje do tego, co możemy o nim wiedzieć, obserwując go w aktualnej, nowej dla nas sytuacji. Wiedza nierozerwalnie wiąże się z mówieniem (por. Danielewiczo- 
wa 2002: 23-24, 97-106), choćby w tym zakresie, że doświadczanie określonego stanu epistemicznego (niekoniecznie najmocniejszej mentalnie wiedzy) czy też powstanie w czyimś umyśle jakiegoś sądu implikuje gotowość powiedzenia czegoś o czymś8. Obmyślaną formułę eksplikacyjną predykatu dziwny można by więc budować wokół prostego pojęcia wiedzy. Można, nie: trzeba, bo z punktu widzenia tego, jak rozpatrywane wyrażenie funkcjonuje, istotniejsze wydaje się mówienie (zresztą również proste znaczeniowo, por. listę indefinibiliów w: Wierzbicka 1996). Wybór przez mówiącego słowa dziwne wynika bowiem z czegoś w rodzaju niemocy nominacyjnej, skierowanej na zwracającą czyjąś uwagę cechę kogoś lub czegoś, i związanego z nią poszukiwania odpowiedniego określenia, które zdoła ująć istotę zauważonej inności czegoś / kogoś. W grę wchodzi zatem bardziej kwestia w y rażenia, nazwania tego, co jest inne i zwraca czyjąś uwagę, aniżeli rozpatrywania tego w płaszczyźnie mentalnej (choć efekt epistemiczny bez wątpienia towarzyszy opisywanej predykacji). Słuszność proponowanej linii interpretacyjnej znaczenia dziwnego można potwierdzić układami sekwencyjnymi w rodzaju tego przytoczonego poniżej, oddającego atmosferę i motywacje orzekania dziwności:

(35) To dziecko jest dziwne.

- Czyli jakie?

- Nie wiem, nie potrafię powiedzieć. Dziwne jest. Po prostu dziwne.

Zauważmy, że swoista bezradność orzekającego, polegająca na nieumiejętności dookreślenia istoty tego, o kim orzeka się dziwność, jest w wypadku rozpatrywanej predykacji dopuszczalna, może nawet naturalna. Ktoś, kto uznaje kogoś lub coś za dziwne, nie potrafi powiedzieć, na czym dokładnie polega zauważona przez niego inność bytu, który stara się scharakteryzować. Jest to znamienne właśnie dla dziwności, analogiczne układy z innymi wyrażeniami o zbliżonych właściwościach semantycznych podobnej reakcji ani nawet dopytania o wyjaśnienie raczej nie dopuszczają, por. np.:

8 Trudno nie zgodzić się z A. Bogusławskim, że od „«mówienia, że_», nie od żadnych innych aktów, zaczyna się całe królestwo świadomości” (Bogusławski 2005: 146). Akty mówienia, że_, przeciwstawiane mówieniu cytacyjnemu (mówić:_), uznaje autor za działania na wiedzy. 
(36) To dziecko jest osobliwe.

- *Czyli jakie?

- *Nie wiem, nie potrafię powiedzieć. Osobliwe jest. Po prostu osobliwe.

W świetle zaprezentowanych ustaleń znaczenie przymiotnika dziwny proponuję definiować następująco:

(37)

dziwny

'inny niż a

i taki, że nie potrafię powiedzieć wszystkiego o tym, jaki jest'

Uzasadnienia domagają się dwie rzeczy. Pierwsza dotyczy zastosowania w powyższym zapisie komponentu 'wszystko'. Chodzi głównie o to, że orzekając o czymś / kimś dziwność, c o ś o tym, czemu / komu przypisujemy tę właściwość, wiemy, a więc i potrafimy to powiedzieć, potrafimy przybliżyć zauważoną inność, problem powstaje wówczas, gdy pojawiają się próby precyzyjnego ujęcia cechy czegoś / kogoś skomentowanej za pomocą przymiotnika dziwny, określenia jej istoty, bardzo często jej przyczyny. Do możliwie prostego ujęcia przytoczonych wyżej treści najbardziej adekwatne wydaje się sformułowanie z udziałem słowa wszystko. Druga sprawa wiąże się z ryzykiem zbudowania definicji za szerokiej. Za pomocą formuły (37) można bowiem próbować objaśniać znaczenie przymiotników nieokreślony lub zagadkowy. Wydaje się jednak, że ani nieokreśloność, ani zagadkowość nie implikują w sposób konieczny inności.

W zakończeniu tych rozważań wypadałoby w kontekście ustalonych danych dotyczących języka odpowiedzieć na pytanie tytułowe. Jaki jest dziwny świat czy też dlaczego ten świat jest dziwny? Bo jest inny niż świat przez nas wyobrażony, odbiega od światów nie tyle istniejących, ile dających się pomyśleć (zwłaszcza że dziwność świata to w zasadzie dziwność ludzkiego działania). Niełatwo taki świat zrozumieć, a więc - innymi słowy - to, co o nim wiemy, nie pasuje do tego, co możemy o nim wiedzieć, obserwując go na nowo i doświadczając jego przejawów w aktualnie zaistniałej sytuacji; prościej i, powiedzmy, definicyjnie rzecz ujmując - nie potrafimy dokładnie określić jego istoty, nie potrafimy powiedzieć wszystkiego o tym, jaki jest. A przechodząc od spraw słowa do spraw życia, poczynione próby interpreta- 
cji dziwnego świata można podsumować pozajęzykoznawczą refleksją: świat i składające się na niego ludzkie działania oraz ich motywacje stanowią zagadkę, której chyba nikt nigdy do końca nie pojmie. Dlatego słowa znanej piosenki, z którą kojarzy się tytułowe określenie, prawdopodobnie zawsze będą aktualne.

\section{Bibliografia}

BogusŁawski A., 2005, Do teorii czasownika powiedzieć, Polonica 24-25, s. 139-155. BogusŁaWski A., 2008, Semantyka, pragmatyka. Leksykografa głos demarkacyjny, Warszawa: Wydawnictwo TAKT.

Boryś W., 2005, Stownik etymologiczny języka polskiego, Kraków: Wydawnictwo Literackie.

Buttler D., 1978, Rozwój semantyczny wyrazów polskich, Warszawa: Wydawnictwa Uniwersytetu Warszawskiego.

Danielewiczowa M., 2002, Wiedza i niewiedza. Studium polskich czasowników epistemicznych, Warszawa: Katedra Lingwistyki Formalnej UW.

ISJP: BAŃKo M. (red.), 2000, Inny stownik języka polskiego, t. 1-2, Warszawa: Wydawnictwo Naukowe PWN.

MARYN D., 2009, O znaczeniach przedmiotowych i metatekstowych przymiotników zwykty i zwyczajny, w: B. Milewska, S. Rzedzicka (red.), Wokót słów i znaczeń III. Z zagadnień semantyczno-leksykalnych, Gdańsk: Wydawnictwo Uniwersytetu Gdańskiego, s. 293-300.

Przepiórkowski A., Bańko M., Górski R. L., Lewandowska-Tomaszczyk B. (red.), 2012, Narodowy Korpus Języka Polskiego, Warszawa: Wydawnictwo Naukowe PWN.

PSWP: ZGóŁKOWA H. (red.), 1994-2005, Praktyczny stownik wspótczesnej polszczy$z n y$, t. 1-50, Poznań: Wydawnictwo Kurpisz.

SJPSz: SzymCZaK M. (red.), 1988-1989, Stownik języka polskiego, t. 1-3, Warszawa: Wydawnictwo Naukowe PWN.

Stanosz B., 1977, Próba rewolucji w lingwistyce, w: B. Stanosz (red.), Lingwistyka a filozofia. Wspótczesny spór o filozoficzne założenia teorii języka, Warszawa: Państwowe Wydawnictwo Naukowe, s. 5-18.

SWJP: Dunau B. (red.), 1996, Stownik wspótczesnego języka polskiego, Warszawa: Wydawnictwo Wilga.

USJP: DubIsz S. (red.), 2003, Uniwersalny słownik języka polskiego, t. 1-4, Warszawa: Wydawnictwo Naukowe PWN. 
Wierzbicka A., 1996, Semantics. Primes and Universals, Oxford-New York: Oxford University Press.

\section{What does a strange world exactly mean? - on the meaning of the adjective dziwny and its synonyms}

\section{( s u m m a r y)}

The paper focuses on the Polish adjective dziwny ['strange'] in its most typical position, that is adjacent to a noun. The aim of the analysis is to provide a description of its meaning which leads to proposing its semantic definition. Hence, the connectivity of this adjective is characterised, with a view to indicating possible selectional limitations imposed on nouns which could enter a collocation with it. In order to propose fundamental semantic hypotheses, the analysed lexical properties of the focal adjective are compared with other predicates with a similar meaning, that is expressions such as dziwaczny ['bizzare'], nietypowy ['untypical'], osobliwy ['peculiar'] and specyficzny ['specific']. 